\title{
Culture and Equity in Science Classrooms
}

\section{Julia Svoboda Gouvea*}

Department of Education, Tufts University, Medford, MA 02155

$\mathrm{T}$ he Current Insights feature is intended to highlight diverse perspectives on teaching, learning and cognition from outside life sciences education. In this installment, I feature recent examples of scholarship examining the intersections between culture and equity in science education. The articles in this set build on intuitions we may hold as biology educators and researchers: The first is that cultural differences can perpetuate inequities in science education. The second is that cultural diversity is beneficial to science learning for all students.

\section{LISTENING FOR CULTURAL AND LINGUISTIC DIVERSITY}

Robertson, A. D., \& Atkins Elliott, L. J. (2017). "All Students Are Brilliant": A Confession of Injustice and a Call to Action. The Physics Teacher, 55(9), 519-523. https://doi.org/10.1119/1.5011823

There is an implicit assumption and hope that more active, student-centered classrooms will also be more equitable. In this essay Robertson and Atkins Elliot reveal the inadequacy of this hope.

The authors are advocates and practitioners of responsive teaching, an approach to instruction that can potentially promote equitable participation in science learning (Robertson et al., 2015). A fundamental principle of responsive teaching is to assume that students' contributions have disciplinary value - in other words- "all students are brilliant." This assumption is built on a foundation of work that has found scientific value in students' thinking across a range of ages and backgrounds (e.g., Hammer and van Zee, 2006; Rosebery et al., 2010). The charge of responsive teaching is to draw out the productive "seeds of science" in students' thinking and make those ideas and questions central to classroom activity.

In principle, then, responsive teaching involves eliciting and listening for the disciplinary value in the contributions of all students. In practice, Robertson and Atkins Elliot argue, cultural and linguistic differences make it challenging for instructors to "see" the science in the contributions of some students. Specifically, middle-class, white, academically trained instructors are likely to have an easier time hearing and understanding students from similar cultural backgrounds. This effect can lead to systematic exclusion of ideas or questions raised by students from nondominant cultures.

The authors illustrate this dilemma with specific examples drawn from the literature and from their own physics classrooms.

In one example, drawn from mathematics education (Gee, 2004), the authors illustrate how two students can provide the same answer, but one student's reasoning can appear more "sophisticated," because it matches dominant cultural expectations. In the example, two third-grade students complete the sequence: $2,5,8$ with the number 11. Stephany, a middle-class student, explains her answer by referencing her method of "counting by 3s," while James, a working-class student, recounts his past experiences playing school with his sister. While both students are attempting to explain how they got their answer, for the authors (and this author), Stephany's reasoning is more obviously mathematical. It is less easy to follow how James got from playing school with his sister to the number 11. The authors admit that, in such circumstances, it would be easy to encourage Stephany's thinking and to overlook James's.
CBE Life Sci Educ December 1, 2018 17:fe8 DOI:10.1187/cbe.18-07-0124

This feature is designed to point $C B E-$ Life Sciences Education readers to current or noteworthy articles for life science educators and education researchers. We invite readers to suggest current themes or articles of interest in life science education as well as influential papers published in the more distant past or in the broader field of education research to be featured in Current Insights. Please send any suggestions to Julia.Gouvea@tufts.edu.

*Address correspondence to: Julia Svoboda Gouvea (Julia.Gouvea@tufts.edu).

() 2018 J. S. Gouvea. CBE-Life Sciences Education @ 2018 The American Society for Cell Biology. This article is distributed by The American Society for Cell Biology under license from the author(s). It is available to the public under an Attribution-Noncommercial-Share Alike 3.0 Unported Creative Commons License (http://creativecommons.org/licenses/ by-nc-sa/3.0).

"ASCB®" and "The American Society for Cell Biology ${ }^{\circledR}$ " are registered trademarks of The American Society for Cell Biology. 
In another example, Robertson and Atkins Elliot confess unfamiliarity with "topic-associative discourse," a speech pattern common in some African-American communities. Topic-associative narratives link together detailed accounts of personal experiences, often twining them together rather than laying them out in sequence. These narratives sound very different from the more linear, causally driven forms of talk common in white middle-class communities. Once again, this cultural-linguistic difference in structure can make it more challenging to notice the substance of what students are trying to communicate.

Robertson and Atkins Eliot's essay is a call for action: they call on instructors to join them in becoming more aware of the role of cultural differences in systematically promoting inequities; and they call for more research, particularly in the form of case studies that will help them and others recognize the "seeds of science" in culturally diverse ways of thinking and talking.

\section{HIDDEN CULTURAL EXPECTATIONS IN SCIENCE EDUCATION}

Bang, M., Warren, B., Rosebery, A. S., \& Medin, D. (2013). Desettling expectations in science education. Human Development, 55(5-6), 302-318. https://doi.org/10.1159/ 000345322

Scientific knowledge is tentative and revisable; yet in science education, expectations of what ideas are worthy of consideration are relatively fixed. Bang and colleagues reveal how culture sets expectations of which ideas are "scientific" and which ideas will be labeled "naïve" or "unsophisticated."

Consider the following example presented by the authors:

A seventh grade class is having a discussion about the characteristics that separate living and non-living things. Jonathan, an African-American male, raises the following question: "If the sun is nonliving, then how does it like produce the flowers ... cuz like if you think about it, if something's dead, how does it help another thing out?"

Bang and colleagues show how Jonathan's question violates the expectations of the science curriculum in which the categories living and nonliving exist as a clear binary. The authors refer to such expectations as "settled"-whether or not the sun is alive is not typically up for debate in science classrooms. Further, they identify the living-nonliving binary ${ }^{1}$ as rooted in the culture of Western science to the exclusion of other perspectives-specifically indigenous ways of knowing that entail more fluid definitions of life.

The authors use this example to highlight two problems. First, when students' contributions do not conform to the expectations of the science curriculum, their ideas are more

\footnotetext{
${ }^{1}$ This example is particularly compelling, given research on the role of viruses in oceanic ecosystems (e.g., Suttle, 2007), where they impact matter and energy cycling and community composition. Viral populations are recognized as having "life-history" strategies (r or K selected) and are categorized using diversity indices used to quantify species diversity. Even if these studies have not resulted in a change of categorization, they make it clear how scientists must effectively twist the definition of life to ask questions like: How does the genetic diversity of viral populations effect the diversity and species abundance in marine communities?
}

likely to be dismissed. Because Western science has defined the curriculum, it is more likely for students from nondominant communities to be shut out. Like Robertson and Atkins Elliot, Bang and colleagues point to how this structure reinforces systematic inequities.

Second, they argue that Jonathan's question has scientific value and that, in passing it over, the class missed an opportunity to more deeply consider the meaning of the definitions they were supposed to be learning about. Jonathan contests a definition on the grounds that it does not meaningfully capture variation in the natural world. According to the authors, Jonathan is critiquing "a logic that locates the sun and a toy rocking horse in the same category." And contesting, rather than blindly accepting, presented definitions should be recognized as good scientific thinking.

Bang and colleagues next present a case of contestation from professional biological science. Drawing on the work of anthropologists of science, they recount how the discovery of horizontal gene transfer disrupted the once-settled view of life as a bifurcating tree of descent with modification. Indeed, the prevalence of horizontal genetic transfer has led to debates about whether patterns of descent should be described as more weblike than treelike (e.g., Soucy et al., 2015). Bang and her coauthors argue that such "desettling" events are part of science.

In science classrooms, the process of desettling can reframe Jonathan's contribution as valuable, simultaneously supporting equity and intellectual rigor.

\section{CULTURE INFLUENCES COGNITION}

ojalehto, b. 1., Medin, D. L., Horton, W. S., Garcia, S. G., \& Kays, E. G. (2015). Seeing Cooperation or Competition: Ecological Interactions in Cultural Perspectives. Topics in Cognitive Science, 7(4), 624-645. https://doi.org/10.1111/ tops. 12156

ojalehto and colleagues are cognitive scientists who study the influences of culture on cognition. In this recent work, they examine cultural differences in how people think about the natural world. To preview their method, try the following thought experiment: coyotes and badgers are both predators that hunt ground squirrels. How would you characterize the relationship between coyotes and badgers?

The authors presented this scenario to people from two different cultural groups: U.S. undergraduates and indigenous Ngöbe of Panama. They did so by showing participants an illustrated, wordless nonfiction book depicting coyotes and badgers hunting ground squirrels. Participants were asked to narrate what they saw.

The majority of U.S. participants interpreted the relationship as competitive, whereas the majority of Ngöbe participants interpreted it as cooperative. Ngöbe were also more likely to describe the species as intentionally communicating with one another and making decisions based in morality.

The authors reveal that, according to behavioral ecologists, "The two [species] hunt cooperatively by giving joint chase or trapping squirrels in tunnels, with the badger digging from below while the coyote waits at burrow exits (Kiliaan et al., 1991; Minta et al., 1992)." Studies have also found evidence of interspecies social bonding in the form of play, body contact, and cosleeping between the two predators. 
This research is not intended to position either indigenous Ngöbe or U.S. participants as "incorrect," but is meant to demonstrate how culture can allow for two different perspectives on the same phenomenon. The authors are careful not to claim that culture is predictive of cognition-some U.S. participants did see cooperation and some Ngöbe did talk of competition. Still, this work reveals how culture, not just our innate humanness, can influence how we think about the natural world.

The authors raise implications of this work for how people from different cultures conceptualize and ultimately act (or do not act) on environmental issues. For example, prior work has found that U.S. undergraduates often describe the relationship between humans and other species as necessarily competitive: attempts to conserve species must result in costs for humans. ojalehto and colleagues suggest that these views may have cultural roots.

For biology education, this work offers an example of relevant cultural differences in thinking about ecological concepts. The work of Bang and colleagues can help us imagine how, within the settled curriculum, a student who challenged culturally dominant expectations about competition might be dismissed. The coyote-badger example illustrates how such a dismissal would undermine both equity and the science.

\section{REFERENCES}

Gee, J. P. (2004). Situated language and learning: A critique of traditional schooling. New York: Psychology Press.

Hammer, D., \& van Zee, E. (2006). Seeing the science in children's thinking Case studies of student inquiry in physical science. Portsmouth, $\mathrm{NH}$ : Heinemann.

Kiliaan, H. P. L., Mamo, C., \& Paquet, P. C. (1991). A coyote, Canis latrans, and badger, Taxidea taxus, interaction near Cypress Hills Provincial Park, Alberta. Canadian Field Naturalist, 105(1), 122-123.

Minta, S. C., Minta, K. A., \& Lott, D. F. (1992). Hunting associations between badgers (Taxidea taxus) and coyotes (Canis latrans). Journal of Mammalogy, 74(4), 814-820

Robertson, A., Scherr, R. E. \& Hammer, D., (Eds.), (2015). Responsive teaching in science and mathematics. New York: Routledge.

Rosebery, A. S., Ogonowski, M., Dischino, M., \& Warren, B. (2010). "The coat traps all your body heat": Heterogeneity as fundamental to learning Journal of the Learning Sciences, 19(3), 322-357. https://doi.org/ 10.1080/10508406.2010.491752

Soucy, S. M., Huang, J., \& Gogarten, J. P. (2015). Horizontal gene transfer: Building the Web of life. Nature Reviews Genetics, 16(8), 472-482 https://doi.org/10.1038/nrg3962

Suttle, C. A. (2007). Marine viruses-Major players in the global ecosystem Nature Reviews Microbiology, 5(10), 801-812. https://doi.org/10.1038/ nrmicro1750 